\title{
CHEMICAL PROPERTIES OF SOILS TREATED WITH BIOLOGICAL SLUDGE FROM GELATIN INDUSTRY(1)
}

\author{
Rita de Cássia Melo Guimarães ${ }^{(2)}$, Mara Cristina Pessôa da Cruz ${ }^{(3)}$, \\ Manoel Evaristo Ferreira(4) \& Carlos Alberto Kenji Taniguchi ${ }^{(5)}$
}

\begin{abstract}
SUMMARY
The impact of agro-industrial organic wastes in the environment can be reduced when used in agriculture. From the standpoint of soil fertility, residue applications can increase the organic matter content and provide nutrients for plants. This study evaluated the effect of biological sludge from gelatin industry on the chemical properties of two Ultisols (loamy sand and sandy clay) and an Oxisol (clay). The experiment lasted 120 days and was carried out in laboratory in a completely randomized design with factorial arrangement, combining the three soils and six biological sludge rates $\left(0,100,200,300,400\right.$, and $\left.500 \mathrm{~m}^{3} \mathrm{ha}^{-1}\right)$, with three replications. Biological sludge rates of up to $500 \mathrm{~m}^{3} \mathrm{ha}^{-1}$ decreased soil acidity and increased the effective cation exchange capacity (CEC) and N, $\mathrm{Ca}, \mathrm{Mg}$, and $\mathrm{P}$ availability, without exceeding the tolerance limit for $\mathrm{Na}$. The increase in exchangeable base content, greater than the effective CEC, indicates that the major part of cations added by the sludge remains in solution and can be lost by leaching.
\end{abstract}

Index terms: waste, nutrients, soil pH, effective CEC.

\section{RESUMO: ATRIBUTOS QUIMICOS DE SOLOS TRATADOS COM LODO BIOLÓGICO DE INDÚSTRIA DE GELATINA}

O impacto dos resíduos orgânicos agroindustriais no ambiente pode ser reduzido com o seu uso agrícola. Do ponto de vista da fertilidade do solo, o que se deseja com a aplicação

\footnotetext{
(1) Part of the master's thesis of the first author presented at the UNESP - Univ Estadual Paulista. Received for publication in January 20, 2010 and approved in December 7, 2011

(2) Faculdades Integradas Fafibe, CEP 14701-070 Bebedouro (SP), Brasil. E-mail: rcmguimaraes@fafibe.br

(3) Faculdade de Ciências Agrárias e Veterinárias, UNESP - Univ Estadual Paulista. CEP 14884-900 Jaboticabal (SP), Brasil. E-mail: mcpcruz@fcav.unesp.br

(4) Faculdade de Ciências Agrárias e Veterinárias, UNESP. E-mail: evaristo@fcav.unesp.br

(5) Embrapa Agroindústria Tropical. CEP 60511-110 Fortaleza (CE), Brasil. E-mail: carlos.taniguchi@embrapa.br
} 


\begin{abstract}
dos resíduos é aumentar o teor de matéria orgânica e fornecer nutrientes para as plantas. Neste trabalho, objetivou-se avaliar o efeito do lodo biológico de indústria de gelatina em atributos químicos de dois Argissolos Vermelho-Amarelos (PVA-arenoso e PVA-textura média) e de um Latossolo Vermelho (LV-argiloso). O experimento foi conduzido por 120 dias em laboratório, em delineamento inteiramente casualizado e esquema fatorial combinando os três solos e seis doses de lodo $\left(0,100,200,300,400\right.$ e $\left.500 \mathrm{~m}^{3} \mathrm{ha^{-1 }}\right)$, com três repetições. A aplicação de até $500 \mathrm{~m}^{3} \mathrm{ha}^{-1}$ de lodo diminui a acidez do solo e aumenta a CTC efetiva e a disponibilidade de $\mathrm{N}, \mathrm{Ca}, \mathrm{Mg}$ e $\mathrm{P}$, sem ultrapassar o limite de tolerância para Na. O aumento do teor de bases, maior do que o da CTC efetiva, indica que a maior parte dos cátions adicionados pelo lodo permanece em solução e pode ser perdida por lixiviação.
\end{abstract}

Termos de indexação: resíduo, nutrientes, $\mathrm{pH}$ do solo, CTC efetiva.

\section{INTRODUCTION}

The food processing industry produces waste of plant or animal origin; the composition depends on the raw material, and the residues can usually be applied to the soil without major risks but with benefits. Vinasse and whey are examples of this group, both liquid wastes, generated in very large quantities and used in agriculture. In view of the amount of vinasse and the accumulated experience of years of soil application, its use is defined by a specific regulation in the State of São Paulo (CETESB, 2006).

In general, the organic residues from agroindustry provide nutrients to plants and increase the organic matter content and soil $\mathrm{pH}$. Nutrients of organic nature, i.e, $\mathrm{N}, \mathrm{P}$ and $\mathrm{S}$, are particularly interesting, but elements such as $\mathrm{Na}$, common in industrial waste, are often found in the composition along with the nutrients. Vinasse, known as a good K source for plants, also increases the soil $\mathrm{Na}$ content (Brito $\&$ Rolim, 2005). The organic $\mathrm{C}$ in the waste can be released into the atmosphere as $\mathrm{CO}_{2}$ or converted into stable humus (Abreu Jr. et al., 2002). The humification process of the organic components of the residue increases organic matter content, inducing changes in soil properties associated with, e.g., cation exchange capacity (CEC). The change in soil $\mathrm{pH}$ by organic waste application is often due to the presence of phenolic, carboxylic and enolic groups, which can consume protons due to the association of $\mathrm{H}^{+}$with these anions, increasing the pH (Naramabuye \& Haynes, 2007).

Brazil is the world's largest gelatin producer and Gelita is the world's leading company, producing 85,000 tons of gelatin per year, 20,000 of which in Brazil, representing $80 \%$ of the Brazilian gelatin production (Agência de Notícias Brasil Árabe, 2009). One Gelita production unit is located in Mococa, a city in the State of São Paulo which, according to Araújo (2006), produces 12 tons of gelatin and 72 tons of residue daily. In this unit, the residual sludge is separated in two types, consisting of the material settled in the primary and secondary tank, the latter also called biological sludge.

Sludge from the primary settler applied to soil at rates of $0,30,60,90$, and $120 \mathrm{t} \mathrm{ha}^{-1}$ improved the soil chemical properties without contamination: it increased the $\mathrm{pH}$ as well as the $\mathrm{P}, \mathrm{Ca}$ and $\mathrm{Mg}$ contents, resulting in better growth of tanzania grass (Araújo, 2006). This indicates that residue disposal on agricultural soils is a viable and promising practice, in view of the improvement in properties of soil fertility and plant growth.

Despite the lack of research results, it is expected that the biological sludge can be used for agriculture as well. The feasibility of this sludge needs to be evaluated to define appropriate agronomical and environmental criteria for application. Thus, the objective of this study was to evaluate the effect of biological sludge from gelatin industry on soil chemical properties.

\section{MATERIAL AND METHODS}

This laboratory experiment was carried out in Jaboticabal, State of São Paulo (SP) - Brazil, from December 2007 to April 2008. The surface layer $(0-20 \mathrm{~cm})$ of three soils and biological sludge from gelatin industry were sampled and analyzed. The soils, classified as Ultisol (loamy sand), Ultisol (sandy clay) and Oxisol (clay), were sampled from eucalyptus, sugarcane and pine plantations, respectively. Soil samples were air-dried, ground, sieved $(4 \mathrm{~mm})$, homogenized and sampled for chemical (Raij et al., 2001) and particle size analyses (Camargo et al., 2009) (Table 1).

The biological sludge (BS) used in the experiment was residue from gelatin production, provided by Gelita South America, unit Mococa - SP. Soil samples and BS were analyzed at the Soil Fertility Laboratory of FCAV/UNESP, Jaboticabal - SP. The 
Table 1. Particle size and chemical properties of the soils used in the experiment

\begin{tabular}{|c|c|c|c|c|c|c|c|c|c|c|c|}
\hline Soill $^{(1)}$ & $\mathbf{P}$ & OM & $\mathrm{pH} \mathrm{CaCl}_{2}$ & $\mathbf{K}^{+}$ & $\mathrm{Ca}^{2+}$ & $\mathrm{Mg}^{2+}$ & $\mathbf{H}+\mathbf{A l}$ & $\mathrm{Al}^{3+}$ & SB & CEC & $\mathrm{V}$ \\
\hline & $\mathrm{mg} \mathrm{dm^{-3 }}$ & $\mathrm{g} \mathrm{dm} \mathrm{m}^{-3}$ & & 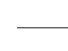 & 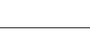 & - & \multicolumn{4}{|c|}{$\mathrm{mmol}_{\mathrm{c}} \mathrm{dm}^{-3}$} & $\%$ \\
\hline Ultisol 1 & 8 & 18 & 5.0 & 1.6 & 15 & 5 & 22 & 1 & 22 & 44 & 50 \\
\hline Ultisol 2 & 7 & 23 & 5.3 & 1.0 & 18 & 9 & 22 & 0 & 28 & 50 & 56 \\
\hline \multirow[t]{2}{*}{ Oxisol } & 16 & 33 & 4.3 & 1.7 & 14 & 5 & 64 & 6 & 21 & 85 & 24 \\
\hline & ${\mathrm{S}-\mathrm{SO}_{4}}^{2-}$ & B & $\begin{array}{c}\mathbf{C u} \\
\mathrm{mg} \mathrm{dm}{ }^{-3}\end{array}$ & $\mathrm{Fe}$ & Mn & $\mathrm{Zn}$ & Clay & & $\begin{array}{l}\text { Silt } \\
\mathrm{kg}^{-1}\end{array}$ & \multicolumn{2}{|c|}{ Sand } \\
\hline Ultisol 1 & 5 & 0.17 & 0.6 & 22 & 112.4 & 0.7 & 100 & & 40 & & 860 \\
\hline Ultisol 2 & 21 & 0.10 & 1.4 & 18 & 3.4 & 0.6 & 350 & & 110 & & 540 \\
\hline Oxisol & 13 & 0.37 & 1.4 & 30 & 156.7 & 1.8 & 560 & & 90 & & 350 \\
\hline
\end{tabular}

(1) Ultisol 1- loamy sand; Ultisol 2 - sandy clay, and Oxisol - clay.

moisture in the sludge was determined by drying BS in porcelain capsules in water bath at about $65^{\circ} \mathrm{C}$ to constant weight. Electrical conductivity (EC) and $\mathrm{pH}$ were determined by direct readings in $\mathrm{BS}$ liquid supernatant; organic-C (Brasil, 2007), total N (Tedesco et al., 1995), $\mathrm{NH}_{4}{ }^{+}-\mathrm{N}$ and $\mathrm{NO}_{3}{ }^{-}-\mathrm{N}$ (Cantarella \& Trivelin, 2001), and P, K, Ca, Mg, and Na contents (Carmo et al., 2000) were also determined. Except for $\mathrm{pH}$ and $\mathrm{EC}$, the BS properties are expressed on a dry basis, assuming a moisture content of $98.35 \%$, as follows: $\mathrm{pH}, 8.4 ; \mathrm{EC}, 4.21 \mathrm{mS} \mathrm{cm}^{-1}$; organic-C, $132 \mathrm{~g} \mathrm{~kg}^{-1}$; total N, $69 \mathrm{~g} \mathrm{~kg}^{-1} ; \mathrm{NH}_{4}{ }^{+}-\mathrm{N}, 12 \mathrm{~g} \mathrm{~kg}^{-1}$; $\mathrm{NO}_{3}^{-}-\mathrm{N}, 0.10 \mathrm{~g} \mathrm{~kg}^{-1} ; \mathrm{P}, 3.5 \mathrm{~g} \mathrm{~kg}^{-1} ; \mathrm{K}, 1.1 \mathrm{~g} \mathrm{~kg}^{-1} ; \mathrm{Ca}$, $89 \mathrm{~g} \mathrm{~kg}^{-1} ; \mathrm{Mg}, 1.6 \mathrm{~g} \mathrm{~kg}^{-1} ; \mathrm{Na}, 38 \mathrm{~g} \mathrm{~kg}^{-1}$ and $\mathrm{C} / \mathrm{N}$ ratio, 1.9

The experiment was evaluated in a completely randomized design with a factorial arrangement $6 \times 3$, represented by six biological sludge rates, three soils and four replications, totaling 72 plots.

BS rates of $0,100,200,300,400$, and $500 \mathrm{~m}^{3} \mathrm{ha}^{-1}$ were applied to $0.4 \mathrm{dm}^{3}$ of each soil (the rates were calculated based on the $0-20 \mathrm{~cm}$ layer of one hectare).

The soil samples were treated with BS rates (treatments) and deionized water, as required to achieve $70 \%$ of water holding capacity of each soil. Soil + BS + water were mixed by hand on a plastic sheet. The wet samples were transferred to $0.5 \mathrm{~L}$ plastic containers and weighed. The resulting weight was used as reference to maintain soil moisture during the experiment, replacing water every two days. The experiment lasted 120 days and at the end of incubation, the samples were spread on plastic trays to dry. Thereafter, the samples were sieved and analyzed for $\mathrm{pH}$ in $\mathrm{CaCl}_{2}, \mathrm{OM}$, available-P, $\mathrm{Al}^{3+}, \mathrm{Ca}^{2+}, \mathrm{Mg}^{2+}, \mathrm{K}^{+}, \mathrm{Na}^{+}$ contents and $\mathrm{H}+\mathrm{Al}$, by the methods described by Raij et al. (2001), and $\mathrm{NH}_{4}{ }^{+}-\mathrm{N}$ and $\mathrm{NO}_{3}{ }^{-}-\mathrm{N}$, as proposed by Cantarella \& Trivelin (2001). Since in this experiment the application of organic waste was tested in closed containers, and $\mathrm{Ca}^{2+}, \mathrm{Mg}^{2+}$ and $\mathrm{K}^{+}$contents were extracted from the samples with cation exchange resin and $\mathrm{Na}^{+}$was extracted with $1 \mathrm{~mol} \mathrm{~L}^{-1} \mathrm{NH}_{4} \mathrm{Cl}$ solution, the results include the exchangeable + soluble forms. Therefore, the effective cation exchange capacity (ECEC) of soils was determined by the method of Gillman (1979), modified by Fonseca et al. (2005), which eliminates the soluble and exchangeable cations by washing with a $0.1 \mathrm{~mol} \mathrm{~L}^{-1} \mathrm{BaCl}_{2}$ solution. The soil samples were then shaken for $12 \mathrm{~h}$ with a $0.005 \mathrm{~mol} \mathrm{~L}^{-1}$ $\mathrm{MgSO}_{4}$ solution and the ECEC was calculated as the difference between the amount of $\mathrm{Mg}$ added to the sample and measured in the equilibrium solution.

The results were subjected to analysis of variance (F test) and polynomial regression.

\section{RESULTS AND DISCUSSION}

The soil properties directly related to acidity $\left(\mathrm{pH}, \mathrm{H}+\mathrm{Al}\right.$ and $\left.\mathrm{Al}^{3+}\right)$, as well as the effective cation exchange capacity (ECEC) were significantly altered by the BS rates (Figure 1). With the application of $500 \mathrm{~m}^{3} \mathrm{ha}^{-1} \mathrm{BS}$, the $\mathrm{pH}$ increased by $0.4,0.8$ and 1.2 units in the clay, sandy clay and loamy sand soils, respectively, compared to the treatment without BS (Figure 1a). This result can be explained by the higher potential cation exchange capacity (CEC at $\mathrm{pH}$ 7.0) of the clay soil, resulting from the combination of $560 \mathrm{~g} \mathrm{~kg}^{-1}$ clay and $33 \mathrm{~g} \mathrm{dm}^{-3} \mathrm{OM}$, making the soil more resistant to changes in $\mathrm{pH}$, i.e., increasing the buffering capacity. In the loamy sand and sandy clay soils, the lower buffering capacity allowed a greater $\mathrm{pH}$ increase. The increase in soil $\mathrm{pH}$ by $\mathrm{BS}$ application can be primarily explained by the residue $\mathrm{pH}$ (8.4). In the gelatin production process, the raw material, i.e., cowhide scraps and shavings, are treated with sodium hydroxide and lime to extract collagen (Ribeiro, 2007). Moreover, 
the presence of phenolic, carboxylic and enolic groups in the organic fraction of BS may lead to proton consumption by the association of soil $\mathrm{H}^{+}$ with these anions (Naramabuye \& Haynes, 2007). Araújo (2006) observed an increase of one unit in the $\mathrm{pH}$ value by applying $6 \mathrm{t} \mathrm{ha}^{-1}$ (dry basis) of primary sludge from gelatin industry ( $\mathrm{pH}$ 12.5) to an Oxisol.

Soil exchangeable acidity (Figure 1b) and potential acidity (Figure 1c) decreased with increasing BS rates. Initially, exchangeable acidity was not observed in the sandy clay soil. In the clay soil, the $\mathrm{Al}^{3+}$ content was reduced by approximately $7 \mathrm{mmol}_{\mathrm{c}} \mathrm{dm}^{-3}$, and in the loamy sand soil, by $2 \mathrm{mmol}_{\mathrm{c}} \mathrm{dm}^{-3}$. The decrease observed in both soils was greater than the initial content (Table 1) since the soil $\mathrm{pH}$ decreased during incubation (Figure 1a, zero rate), resulting in increased exchangeable acidity. In addition to the aluminum precipitation as $\mathrm{Al}$ hydroxide caused by the alkaline inorganic components of BS, the decrease can be associated with $\mathrm{Al}$ complexation by soluble organic substances originally present in the residue and generated during the decomposition process. Parallel to the increase in soil $\mathrm{pH}$, Naramabuye \& Haynes (2007) observed a decrease in exchangeable and soil solution $\mathrm{Al}$ (total and monomeric), probably due to monomeric $\mathrm{Al}$ complexation by soluble organic substances present in poultry, cattle and swine manure, and in sewage sludge.

The potential acidity decreased by approximately 12, 6 and $21 \mathrm{mmol}_{\mathrm{c}} \mathrm{dm}^{-3}$ in the loamy sand, sandy clay and clay soils, respectively (Figure 1c). Since the quantity of bases added with the residue was the same (at each BS rate), the amount of neutralized acid was expected to be approximately equal in all three soils. Still, if the potential acidity of the clay soil had decreased by $21 \mathrm{mmol}_{\mathrm{c}} \mathrm{dm}^{-3}$, the soil $\mathrm{pH}$ would have been expected to be greater than the given (4.5), based on the relation $\mathrm{pH} \mathrm{CaCl} \mathrm{Ca}_{2}=3.66+$ $0.027 \mathrm{~V} \%$ (Quaggio et al., 1982) and assuming that
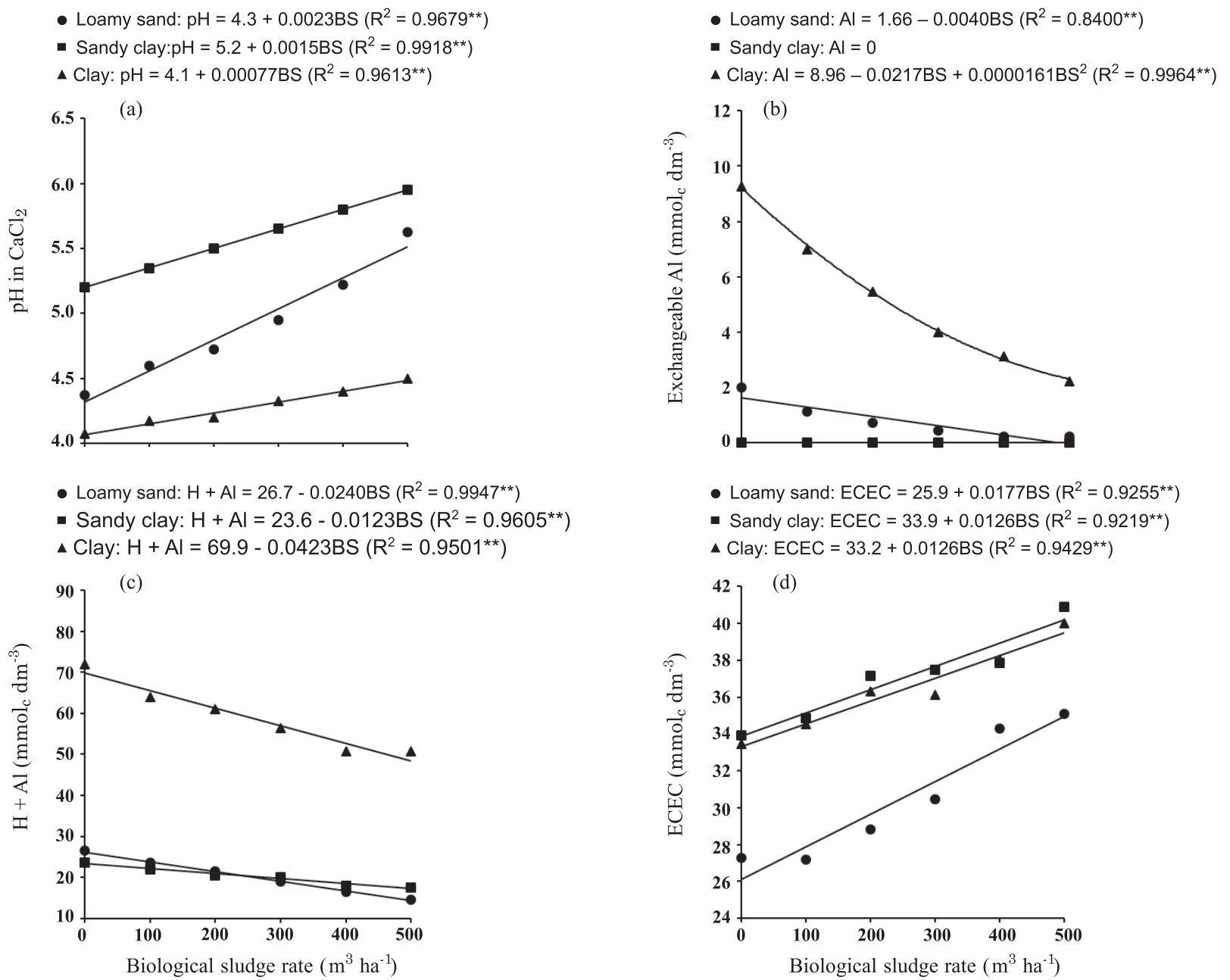

Figure 1. Effect of rates of biological sludge (BS) from gelatin industry on the pH (a), exchangeable $\mathrm{Al}$ (b), potential acidity $(\mathrm{H}+\mathrm{Al}, \mathrm{c})$ and effective cation exchange capacity $(\mathrm{ECEC}, \mathrm{d})$ of three soils, 120 days after BS application. 
the potential CEC remained unchanged after BS application, since the OM content was not altered by the residue, as explained below. Thus, the decrease in potential acidity determined by the SMP buffer solution was overestimated. The primary sludge from gelatin industry evaluated by Araújo (2006) had a similar effect on an Oxisol, decreasing the $\mathrm{H}+\mathrm{Al}$ (SMP method) in $16 \mathrm{mmol}_{\mathrm{c}} \mathrm{dm}^{-3}$ at a $\mathrm{CEC}$ of $81 \mathrm{mmol}_{\mathrm{c}} \mathrm{dm}^{-3}$.

The ECEC increased in all soils (Figure 1d). The figure shows that the increase in ECEC was approximately 9, 6 and $6 \mathrm{mmol}_{\mathrm{c}} \mathrm{dm}^{-3}$ in loamy sand, sandy clay and clay soils, respectively. The decrease in potential soil acidity, in soils with low or no exchangeable acidity, should be close to the increase of ECEC, which in turn must match the increase in the sum of base (SB) value. For the clay soil, the difference between the decrease in potential acidity, determined by SMP buffer solution $\left(21 \mathrm{mmol}_{\mathrm{c}} \mathrm{dm}^{-3}\right)$, and increase in ECEC $\left(6 \mathrm{mmol}_{\mathrm{c}} \mathrm{dm}^{-3}\right)$, determined by the compulsive exchange method (Fonseca et al., 2005) was therefore great, despite the initial $9 \mathrm{mmol}_{\mathrm{c}} \mathrm{dm}^{-3} \mathrm{Al}^{3+}$ of the soil. This result reinforces the earlier comment, that the SMP method overestimated the potential acidity decrease in clay soil. Increases in ECEC with the application of organic waste were also reported by Trannin et al. (2008). In a field experiment, the authors observed increases in exchangeable $\mathrm{K}^{+}, \mathrm{Ca}^{2+}, \mathrm{Mg}^{2+}$ and $\mathrm{Na}^{+}$soil contents, which was associated with an increase in ECEC in response to the application of biosolids from fiber and PET (polyethylene terephthalate) resin industry. Fonseca (2001) reported an increase in the ECEC value with treated sewage sludge application and explained the result by the increase in the $\mathrm{Ca}^{2+}$, $\mathrm{Mg}^{2+}, \mathrm{K}^{+}$, and especially $\mathrm{Na}^{+}$contents.

The contents of $\mathrm{NH}_{4}{ }^{+}-\mathrm{N}$ and $\mathrm{NO}_{3}-\mathrm{N}$ increased with $\mathrm{BS}$ rates, and the quadratic model fit best for $\mathrm{NH}_{4}{ }^{+}-\mathrm{N}$ in clay soil and $\mathrm{NO}_{3}{ }^{-}-\mathrm{N}$ in loamy sand soil. In the other cases, the positive linear model fit better (Figure 2a,b). The applied BS contained about $17 \%$ of total $\mathrm{N}$ as ammonium, and since the $\mathrm{C} / \mathrm{N}$ ratio of the residue was low, the conditions were very favorable for mineralization. Araújo (2006) did not assess the mineral-N contents in the soil after application of primary sludge from the gelatin industry, but observed a linear increase in N uptake by tanzania guinea grass. A similar result was obtained with maize plants treated with up to $500 \mathrm{~m}^{3} \mathrm{ha}^{-1} \mathrm{BS}$ from gelatin industry (Taniguchi, 2010). An increase in soil mineral-N in areas of application of other wastes was frequently reported (Smith et al., 1998; Vieira \& Cardoso, 2003; Boeira \& Maximiliano, 2009). Taniguchi (2010) found that mineral-N increased in an Ultisol (sandy clay loam) proportionally to the application of BS from gelatin industry.

$\mathrm{NH}_{4}{ }^{+}-\mathrm{N}$ contents in the clay soil suggest the lower efficiency of nitrification reactions, which could be explained by the higher acidity of this soil than of the others. The $\mathrm{pH}$ is the main factor regulating nitrification, which occurs between $\mathrm{pH} 4.5$ and 10.0, with optimum $\mathrm{pH}$ at about 8.5 (Havlin et al., 2005). In soils with $\mathrm{pH}$ values between 3.4 and 4.4, Sahrawat (1982) found no nitrate production after aerobic incubation for four weeks, although he reported the formation of ammonium N. However, the method used to measure the soil $\mathrm{pH}$ may fail to reflect the $\mathrm{pH}$ value at microsites where nitrification occurs. Darrah et al. (1987) suggested that the nitrifying microorganisms acidify the soil volume under their direct influence by releasing $\mathrm{H}^{+}$protons, to the point of interrupting their proper activity by the resulting acidity. The soil beyond the influence of nitrifying microorganisms maintains its original $\mathrm{pH}$ until the $\mathrm{H}^{+}$ions generated at microsites are diffused, creating an uneven acidity distribution in the total soil volume. Sierra (2006) determined that the minimum $\mathrm{pH}$ (in water) for nitrification was lower at the microsites $(\mathrm{pH}<4.2)$ than in the surrounding soil $(\mathrm{pH}<4.7)$. The initial $\mathrm{pH}$ values were 4.3, 5.0 and 5.3 in clay, loamy sand and sandy clay soils, respectively (Table 1). Despite the complexity of the $\mathrm{pH}$ effect on nitrification, these values indicate more favorable initial conditions for nitrification in the loamy sand and sand clay soils. Still, other soil and climate factors affect the nitrification reactions, which are essentially aerobic. In clay soils, with decomposing organic matter, i.e., with high $\mathrm{O}_{2}$ consumption and high $\mathrm{CO}_{2}$ production, nitrification may be limited if gas exchange is not effective. However, at the end of the incubation period, 204, 199 and $255 \mathrm{mg} \mathrm{dm}^{-3}$ $\mathrm{NO}_{3}-\mathrm{N}$ were recovered, in the loamy sand, sandy clay and clay soils, respectively. Subtracting the $\mathrm{NO}_{3}{ }^{-}-\mathrm{N}$ contents of the soil without BS from the recovered values, it appears that 45,59 and $59 \%$ of total $\mathrm{N}$ added had been nitrified 120 days after BS application to each soil, respectively. Considering the total $\mathrm{N}$ content of the sludge $\left(69 \mathrm{~g} \mathrm{~kg}^{-1}\right)$, at a rate of $100 \mathrm{~m}^{3} \mathrm{ha}^{-1} \mathrm{BS}$, approximately $114 \mathrm{~kg} \mathrm{ha}^{-1} \mathrm{~N}$ were applied. This would result in 51, 67 and $67 \mathrm{~kg} \mathrm{ha}^{-1}$ mineral N produced in 120 days. Taniguchi (2010) determined a mineralization rate of $\mathrm{BS}$ from gelatin industry of over $80 \%$ in 126 days, when applied to an Ultisol (sandy clay loam), and an average half-life of 7.7 days, which is consistent with the nature and $\mathrm{C} / \mathrm{N}$ ratio of the residue, indicating a high leaching potential. When applied to soil columns at rates of up to $500 \mathrm{~m}^{3} \mathrm{ha}^{-1}$, BS from gelatin industry caused increased losses of $\mathrm{NO}_{3}-\mathrm{N}$ in sandy clay loam but not in sandy clay soil. However, the application of up to $170 \mathrm{~m}^{3} \mathrm{ha}^{-1}$ to second-season maize did not alter the soil $\mathrm{NO}_{3}-\mathrm{N}$ content at the end of the crop cycle, down to a depth of $1 \mathrm{~m}$ (Taniguchi, 2010).

Despite the BS quantities applied, no effect on the soil OM content was detected (Figure 2c). About $8.3 \mathrm{t} \mathrm{ha}^{-1}$ dry matter and $0.5 \mathrm{~g} \mathrm{dm}^{-3}$ organic $\mathrm{C}$ were 
- Loamy sand: $\mathrm{NH}_{4}{ }^{+}-\mathrm{N}=3.02+0.0047 \mathrm{BS}\left(\mathrm{R}^{2}=0.6275^{\star}\right)$

- Sandy clay: $\mathrm{NH}_{4}{ }^{+}-\mathrm{N}=3.2+0.0043 \mathrm{BS}\left(\mathrm{R}^{2}=0.8420^{*}\right)$

$\Delta$ Clay: $\mathrm{NH}_{4}{ }^{+}-\mathrm{N}=6.4+0.0054 \mathrm{BS}+0.00007 \mathrm{BS}^{2}\left(\mathrm{R}^{2}=0.9753^{*}\right)$

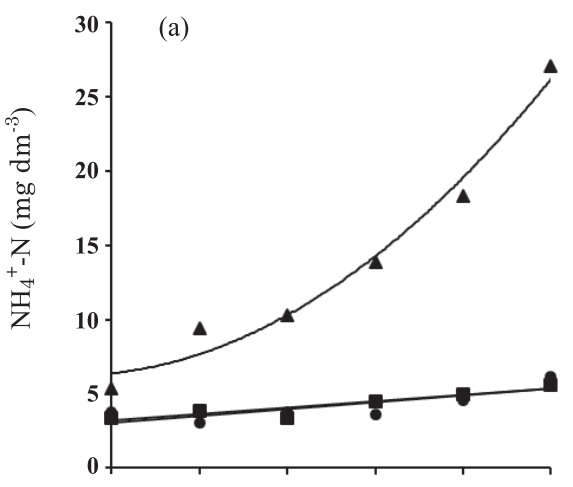

- Loamy sand: $\mathrm{OM}=17.167$

- Sandy clay: $O M=19.125$

Clay: $\mathrm{OM}=33.083$

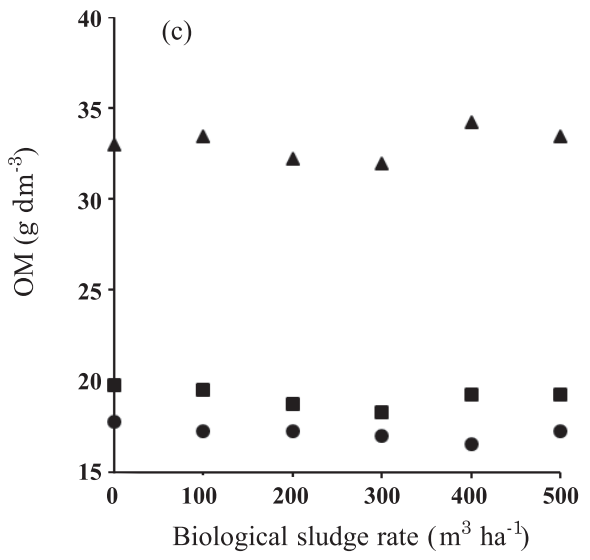

- Loamy sand: $\mathrm{NO}_{3}{ }^{-} \mathrm{N}=76.28+0.47 \mathrm{BS}-0.00043 \mathrm{BS}^{2}\left(\mathrm{R}^{2}=0.9947^{*}\right)$

- Sandy clay: $\mathrm{NO}_{3}{ }^{-} \mathrm{N}=28.58+0.34 \mathrm{BS}\left(\mathrm{R}^{2}=0.9953^{*}\right)$

Clay: $\mathrm{NO}_{3}{ }^{-} \mathrm{N}=84.5+0.34 \mathrm{BS}\left(\mathrm{R}^{2}=0.9973^{*}\right)$

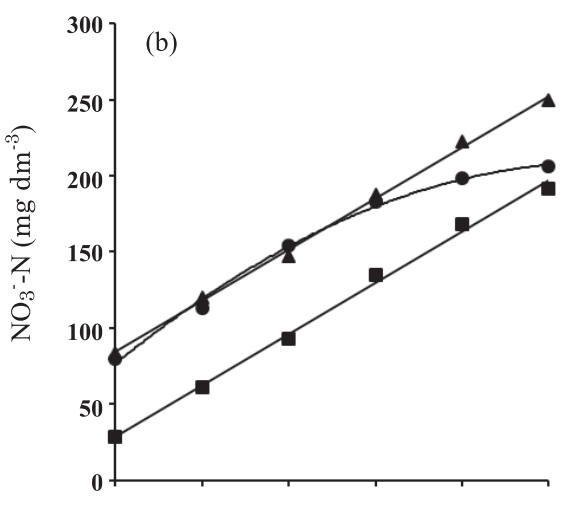

- Loamy sand: $P=4.9+0.019 B S\left(R^{2}=0.9505^{* *}\right)$

- Sandy clay: $P=2.7+0.0091 B S\left(R^{2}=0.9143^{\star \star}\right)$

Clay: $P=12.0+0.0129 B S\left(R^{2}=0.9382^{* *}\right)$

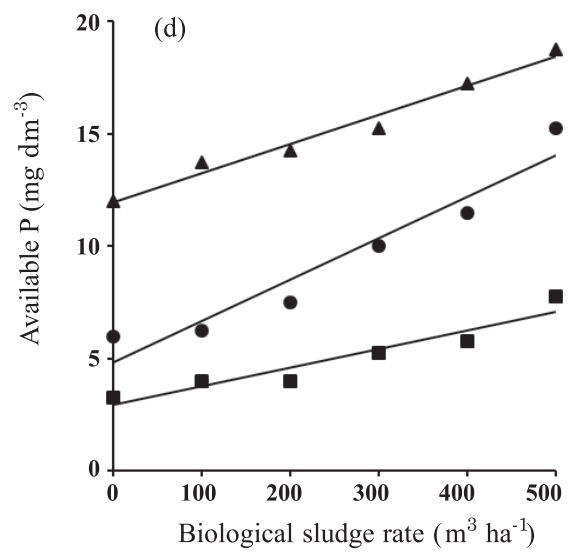

Figure 2. Effect of rates of biological sludge (BS) from gelatin industry on $\mathrm{NH}_{4}^{+}-\mathrm{N}^{(a)}, \mathrm{NO}_{3}^{-}-\mathrm{N}(\mathrm{b}), \mathrm{OM}^{-}(\mathrm{c})$ and available $P$ contents (d) of three soils, 120 days after application.

applied with the highest $\mathrm{BS}$ rate $\left(500 \mathrm{~m}^{3} \mathrm{ha}^{-1}\right)$. The low amount of $\mathrm{C}$ applied, combined with a low $\mathrm{C} / \mathrm{N}$ ratio (1.9) of the $\mathrm{BS}$, must have resulted in rapid mineralization, with no measurable change in the existing reserves of organic $\mathrm{C}$ in soil. Barcelar et al. (2000) observed no significant increases in organic C content by sewage sludge application and concluded that the reason was the rapid mineralization of organic matter of the material used.

Potential cation exchange capacity (CEC at $\mathrm{pH}$ 7.0) was not calculated by the sum of bases plus potential acidity because the experiment was carried out in a closed environment with salt accumulation. As the content of soil organic matter did not vary with the application of BS, the CEC at $\mathrm{pH} 7.0$ was most likely not altered either, reinforcing the above argument explaining the differences between the $\mathrm{H}+\mathrm{Al}$ and ECEC values in the clay soil (Figure 1).

The increase in the available $\mathrm{P}$ content with BS application was linear (Figure 2d), and at the highest rate, $29 \mathrm{~kg} \mathrm{ha}^{-1} \mathrm{P}\left(14.5 \mathrm{mg} \mathrm{dm}^{-3}\right)$ were added. In this case, the recovered were lower than the applied quantities because not all $\mathrm{P}$ was necessarily mineralized, i.e., a part may have been reincorporated into the microbial biomass and another part strongly adsorbed to soil or precipitated with $\mathrm{Al}$ and $\mathrm{Fe}$, becoming non-labile $\mathrm{P}$, not extracted in the analysis. Of the total $\mathrm{P}$ applied with the highest $\mathrm{BS}$ rate, 5,10 and $8 \mathrm{mg} \mathrm{dm}^{-3}$ were not recovered in the loamy sand, sand clay and clay soils, respectively. If the balance were determined by phosphate adsorption only, greater retention would be expected in the clay soil, due to higher acidity and clay content, but the difference between soils was minor. Nevertheless, the greatest increase in available $\mathrm{P}$ with the application of BS was observed in the loamy sand soil, in agreement with Valladares et al. (2003), who stated lower maximum phosphate adsorption capacity in sandy soils.

BS application induced a linear increase in $\mathrm{Ca}$, $\mathrm{Mg}, \mathrm{Na}$ and $\mathrm{K}$ contents (Figure 3a,d). The increase in exchangeable bases, higher for $\mathrm{Ca}$ and $\mathrm{Na}$ and 


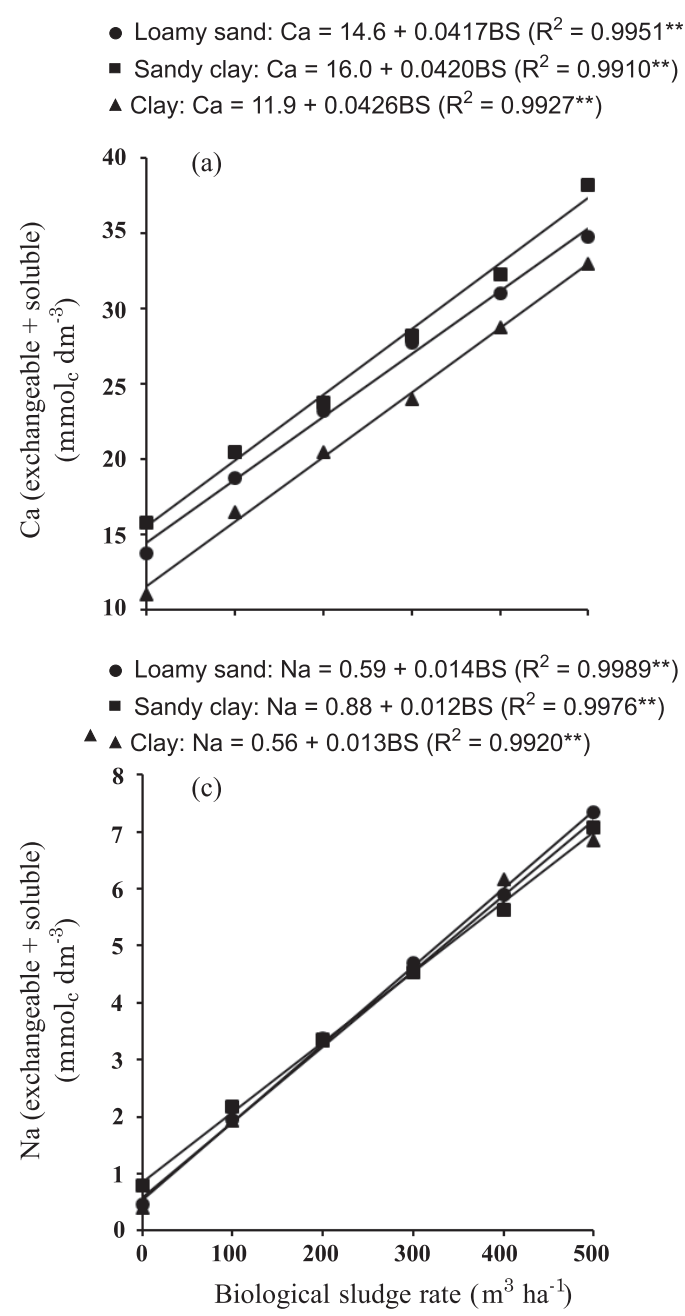

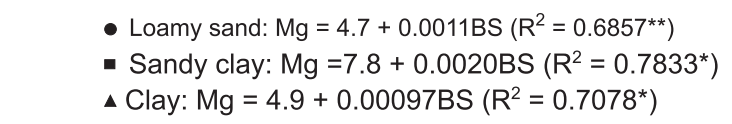
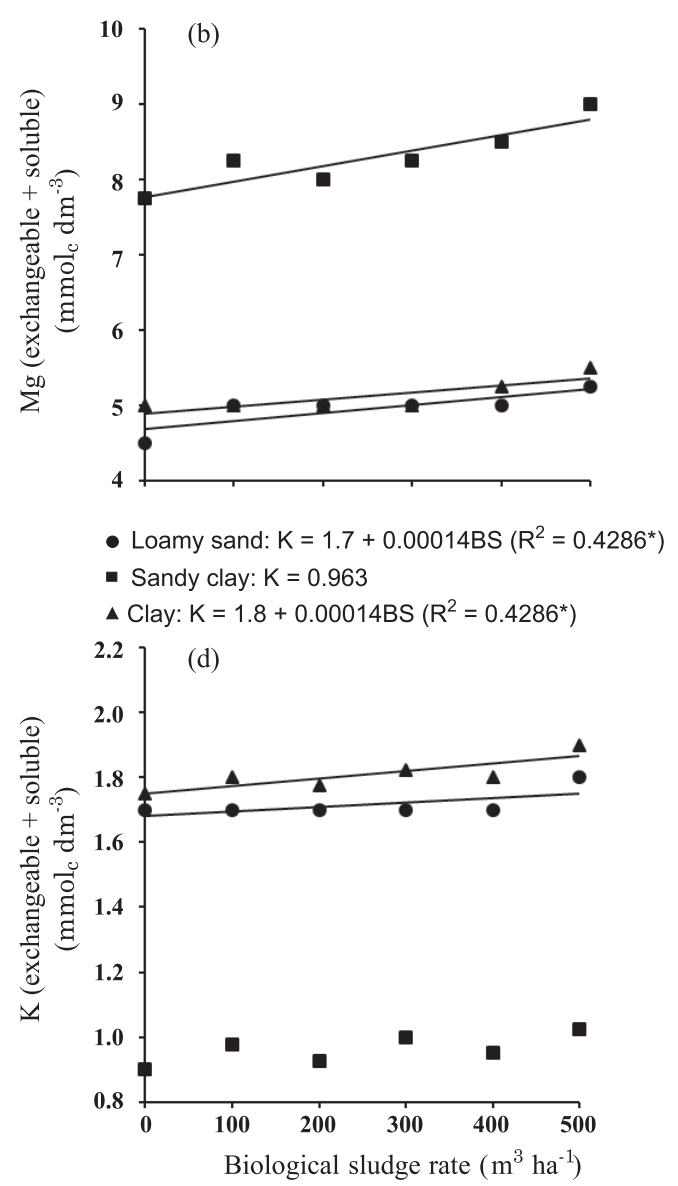

Figure 3. Effect of rates of biological sludge (BS) from gelatin industry on $\mathrm{Ca}(\mathrm{a}), \mathrm{Mg}(\mathrm{b}), \mathrm{Na}(\mathrm{c})$, and $\mathrm{K}$ contents (d) of three soils, 120 days after application.

low for $\mathrm{Mg}$ and $\mathrm{K}$, reflects the composition of BS. Nascimento et al. (2004), Araújo (2006) and Trannin et al. (2008) reported similar results for $\mathrm{Ca}, \mathrm{Mg}$ and $\mathrm{Na}$ when applying organic residues such as sewage sludge, primary sludge from gelatin industry and industrial biosolids, respectively.

The application of $500 \mathrm{~m}^{3} \mathrm{ha}^{-1} \mathrm{BS}$ added quantities of $18.4,1.8,6.9$, and $0.12 \mathrm{mmol}_{\mathrm{c}} \mathrm{dm}^{-3}$, respectively, of $\mathrm{Ca}, \mathrm{Mg}, \mathrm{K}$, and $\mathrm{Na}$. Considering the same $\mathrm{BS}$ rate, amounts of $\mathrm{Ca}, \mathrm{Mg}, \mathrm{Na}$, and $\mathrm{K}$ of $22,1,7$ and $0.2 \mathrm{mmol}_{\mathrm{c}} \mathrm{dm}^{-3}$ were recovered by analysis, that is, greater amounts than the increase in ECEC for the three soils. Therefore, the greatest part of the added elements is not adsorbed and can be lost by leaching. Due to the lower adsorption strength in the solid phase, the $\mathrm{Na}^{+}$cation is more prone to be lost. However, even at the $500 \mathrm{~m}^{3} \mathrm{ha}^{-1}$ $\mathrm{BS}$ rate, the amount of $\mathrm{Na}$ applied (315 kg ha-1) was lower than the annual maximum allowed by the regulations of Cetesb P4.233 (1999) for tannery sludge, determining $400 \mathrm{~kg} \mathrm{ha}^{-1} \mathrm{Na}$ for sandy and sandy-silt soils, and 1,000 $\mathrm{kg} \mathrm{ha}^{-1}$ for organic, silty, clay-silt and clay soils. The regulation for tannery sludge was used, since the standards for sludge (Cetesb P4.230 and Conama Resolution 375) do not mention the theoretically allowed accumulated amount of $\mathrm{Na}$. The application of the regulations for tannery sludge is justified because $\mathrm{Na}$ in residues is usually soluble, so the accumulated amount should be more related to the residue-treated soil than to the proper residue.

\section{CONCLUSIONS}

1. The application of up to $500 \mathrm{~m}^{3} \mathrm{ha}^{-1}$ biological sludge from gelatin industry decreases soil acidity and increases the effective CEC (ECEC) and availability of $\mathrm{N}, \mathrm{Ca}, \mathrm{Mg}$ and $\mathrm{P}$, without exceeding the $\mathrm{Na}$ threshold.

2 . The increase in soil base content, greater than the ECEC, indicates that most part of the cations added by the biological sludge remains in solution and can be lost by leaching. 


\section{LITERATURE CITED}

ABREU Jr., C.H.; MURAOKA, T. \& OLIVEIRA, F.C. Carbono, nitrogênio, fósforo e enxofre em solos tratados com composto de lixo urbano. R. Bras. Ci. Solo, 26:769-780, 2002.

AGÊNCIA DE NOTÍCIAS BRASIL ÁRABE - ANBA. País é o maior celeiro de gelatina do mundo. Available at <http:// www.anba.com.br/noticia_industria.kmf $>$. Accessed Nov 52009 .

ARAÚJO, J.C. Efeito do lodo de indústria de gelatina na fertilidade do solo e no capim-tanzânia. Jaboticabal, Universidade Estadual Paulista - Faculdade de Ciências Agrárias e Veterinárias, 2006. 30p. (Tese de Mestrado)

BARCELAR, C.A.; ROCHA, A.A.; LIMA, M.R. \& POHLMANN, M. Efeito residual do lodo de esgoto alcalinizado em atributos químicos e granulométricos de um Cambissolo Húmico. In: REUNIÃO BRASILEIRA DE FERTILIDADE DO SOLO E NUTRIÇÃO DE PLANTAS, 24., Santa Maria, 2000. Anais... Santa Maria, Sociedade Brasileira de Ciência do Solo, 2000.

BOEIRA, R.C. \& MAXIMILIANO, V.C.B. Mineralização de compostos nitrogenados após aplicações de lodos de esgoto em quatro cultivos de milho. R. Bras. Ci. Solo, 33:207-218, 2009.

BRASIL. Instrução Normativa SDA n 28 , de 27 julho de 2007. Diário Oficial da União, Brasília, DF, 31 jul. 2007. Seção 1, p.11.

BRITO, F.L. \& ROLIM, M.M. Comportamento do efluente e do solo fertirrigado com vinhaça. Agropec. Técnica, 26:60-67, 2005.

CAMARGO, O.A.; MONIZ, A.C.; JORGE, J.A. \& VALADARES, J.M.A.S. Métodos de análise química, mineralógica e física de solos do Instituto Agronômico de Campinas. Campinas, Instituto Agronômico de Campinas, 2009. 77p. (Boletim Técnico, 106)

CANTARELlA, H. \& TRIVELIN, P.C.O. Determinação de nitrogênio inorgânico em solo pelo método da destilação a vapor. In: RAIJ, B.van; ANDRADE, J.C.; CANTARELLA, H. \& QUAGGIO, J.A., eds. Análise química para avaliação da fertilidade de solos tropicais. Campinas, Instituto Agronômico de Campinas, 2001. p.270-276.

CARMO, C.A.F.S.; ARAÚJO, W.S.; BERNARDI, A.C.C. \& SALDANHA, M.F.C. Métodos de análise de tecidos vegetais utilizados na Embrapa Solos. Rio de Janeiro, Embrapa Solos, 2000. 41p. (Circular Técnica, 6)

CETESB. Lodo de curtume: Critérios para o uso em áreas agrícolas e procedimentos para apresentação de projetos. São Paulo, 1999. 35p. (Norma P4.233)

CETESB. Vinhaça - Critérios e procedimentos para aplicação no solo agrícola. São Paulo, 2006. 12p. (Norma P4.231)

DARRAH, P.R.; WHITE, R.E. \& NYE, P.H. A theoretical consideration of the implications of cell clustering for the prediction of nitrification in soil. Plant Soil, 99:387-400, 1987.

FONSECA, A.F. Disponibilidade de nitrogênio, alterações nas características químicas do solo e do milho pela aplicação de efluente de esgoto tratado. Piracicaba, Universidade de São Paulo - Escola Superior de Agricultura Luiz de Queiroz, 2001. 110p. (Tese de Mestrado)
FONSECA, A.F.; ALLEONI, L.R.F.; MELFI, A.J. \& MONTES, C.R. Cation exchange capacity of an Oxisol amended with an effluent from domestic sewage treatment. Sci. Agric., 62:552-558, 2005.

HAVLIN, J.L.; BEATON, J.D.; TISDALE, S.L. \& NELSON, W.L. Soil fertility and fertilizers. An introduction to nutrient management. 7.ed. New Jersey, Pearson Education, 2005. $515 p$.

NARAMABUYE, F.X. \& HAYNES, R.J. The liming effect of five organic manures when incubated with an acid soil. J. Plant Nutr. Soil Sci., 170:615-622, 2007.

NASCIMENTO, C.W.A.; BARROS, D.A.S.; MELO, E.E.C \& OLIVEIRA, A.B. Alterações químicas em solos e crescimento de milho e feijoeiro após aplicação de lodo de esgoto. R. Bras. Ci. Solo, 28:385-392, 2004.

QUAGGIO, J.A.; DECHEN, A.R. \& RAIJ, B.van. Efeitos da aplicação de calcário e gesso sobre a produção de amendoim e lixiviação de bases no solo. R. Bras. Ci. Solo, 6:182-194, 1982.

RAIJ, B.van; ANDRADE, J.C.; CANTARELLA, H. \& QUAGGIO, J.A., eds. Análise química para avaliação da fertilidade de solos tropicais. Campinas, Instituto Agronômico de Campinas, 2001. 235p.

RIBEIRO, R.M. Tratamento do resíduo de indústria de gelatina através da compostagem, com emprego de serragem e palha de café. Lavras, Universidade Federal de Lavras Lavras, 2007. 62p. (Tese de Mestrado)

SAHRAWAT, K.L. Nitrification in some tropical soils. Plant Soil, 65:281-286, 1982.

SIERRA, J. A hot-spot approach applied to nitrification in tropical acid soils. Soil Biol. Biochem., 38:644-652, 2006.

SMITH, S.R.; WOODS, V. \& EVANS, T.D. Nitrate dynamics in biosolids-treated soils. I. Influence of biosolids type and soil type. Biores. Technol., 66:139-149, 1998

TANIGUCHI, C.A.K. Mineralização do lodo biológico de indústria de gelatina, atributos químicos de solo e uso fertilizante para produção de milho. Jaboticabal, Universidade Estadual Paulista - Faculdade de Ciências Agrárias e Veterinárias, 2010. 97p. (Tese de Doutorado)

TEDESCO, J.M.; GIANELLO, C.; BISSANI, C.A.; BOHNEN, H. \& VOLKWEISS, S.J. Análises de solo, plantas e outros materiais. Porto Alegre, Universidade Federal do Rio Grande do Sul, 1995. 173p.

TRANNIN, I.C.B.; SIQUEIRA, J.O. \& MOREIRA, F.M.S. Atributos químicos e físicos de um solo tratado com biossólido industrial e cultivado com milho. R. Bras. Eng. Agríc. Amb., 12:223-230, 2008.

VALLADARES, G.S.; PEREIRA, M.G. \& ANJOS, L.H.C. Adsorção de fósforo em solos de argila de atividade baixa. Bragantia, 63:111-118, 2003.

VIEIRA, R.F. \& CARDOSO, A.A. Variações nos teores de nitrogênio mineral em solo suplementado com lodo de esgoto. Pesq. Agropec. Bras., 38:867-874, 2003. 